\title{
COMMENTARY
}

\section{Gene expression in human sepsis: what have we learned?}

\author{
James A Russell* \\ See related research by Tang et al., http://ccforum.com/content/14/6/R237
}

\begin{abstract}
In the previous issue of Critical Care, Tang and colleagues offer a very novel systematic review of 12 studies of gene expression in blood of human sepsis. The review concludes that there is no discernable transition from a pro- to an anti-inflammatory expression phenotype in blood in human sepsis. The authors found that upregulation of pathogen recognition receptors and signal transduction pathways was a consistent theme in expression studies. The review by Tang and colleagues has strengths, including defined screening criteria, broad literature review, strict inclusion criteria, and transparent methods for assessing strengths and weaknesses of studies. There are other issues to consider. First, one source of variation in gene expression studies in sepsis is variability in time from onset of sepsis to time of blood draw. Another source of variation is differences between tissues in gene expression at the same time in sepsis. Whole blood is a mélange of tissues (a variety of leukocytes); therefore, one assesses a weighted sum of all leukocyte classes. About half of the studies assessed peripheral mononuclear cells. A third great source of variable gene expression in sepsis is heterogeneity of causes and microbiology of sepsis. Only one study compared Gram-positive with Gram-negative sepsis. Only three studies confirmed microarray data with an independent measurement of expression. One interpretation is that two of three studies of early sepsis found increased expression of pro-inflammatory genes. In late sepsis, three of six studies found increased expression of pro-inflammatory genes whereas three of six studies found decreased expression of pro-inflammatory genes. The balance of pro- to anti-inflammatory gene expression is difficult to quantify. Sample size is highly variable in studies ( $n=12$ to 176). These limitations require a leap of faith to suggest that the paradigm of sepsis as a pro-inflammatory phenotype that shifts to an anti-inflammatory phenotype is flawed: the absence of evidence in expression studies is not the same as having well-conducted studies with clear negative evidence.
\end{abstract}

In the previous issue of Critical Care, Tang and colleagues [1] offer a very novel systematic review of 12 studies of gene expression in blood of humans who have sepsis. The studies conclude that there was no discernable transition from a pro- to an anti-inflammatory expression phenotype in whole blood in human sepsis. The authors posit that sepsis as a pro-inflammatory phenotype that shifts to an anti-inflammatory phenotype may be flawed. This provocative conclusion disagrees with the evidence (animal and clinical); furthermore, ongoing translational and clinical studies hinge on the premise that there is indeed a transition (at about days 3 to 5 of clinical sepsis) from a brisk pro-inflammatory to an anti-inflammatory phenotype.

*Correspondence: jim.russell@hli.ubc.ca

Critical Care Medicine, St. Paul's Hospital, 1081 Burrard Street, Vancouver, BC, Canada V6Z 1 Y6
The innate immune system is the 'hard-wired' rapid response system of each individual [2]. The first step in recognition of microorganisms is that pattern recognition receptors (such as the Toll-like receptor family) bind to highly conserved molecules called pathogen-associated molecular proteins. Accordingly, Tang and colleagues [1] found that upregulation of pathogen recognition receptors and signal transduction pathways was a consistent theme in expression studies.

The review by Tang and colleagues [1] has strengths, including defined screening criteria, broad literature review, strict inclusion criteria, and transparent methods for assessing strengths and weaknesses of studies to say nothing of the research strengths of the authors. Furthermore, the summary is presented in clear tables accessible to expert and non-expert readers alike.

There are other issues to consider in the review. First, one source of variation in gene expression studies in sepsis is variability in time from onset of sepsis to time of blood draw. The authors found no obvious pattern to 
suggest differences in gene expression over time. However, the only studies that can be sure of onset of sepsis are the human endotoxemia studies (because time of endotoxin administration is known). I do not think that there are enough studies of expression at different times; thus, the authors' conclusion may be premature (but could be proven correct by studies designed to address this important hypothesis).

Another source of variation of gene expression is variability of tissue examined given that different tissues express different genes at the same time in sepsis. Whole blood is a mélange of tissues (a variety of leukocytes); therefore, one assesses a weighted sum of all leukocyte classes. Furthermore, leukocyte differential changes rapidly in sepsis; thus, variability in whole-blood gene expression over time could be confounded by changes in leukocyte differential. About half of the studies assessed peripheral mononuclear cells [3-8].

A third great source of variable gene expression in sepsis is heterogeneity of causes and microbiology of sepsis, yet expression may vary according to cause and microbiology. For example, only one study [9] compared Gram-positive with Gram-negative sepsis. None compared various community-acquired infections (for example, pneumonia versus peritonitis).

There are concerns regarding the quality of data in gene expression $[10,11]$. Only three of these studies confirmed microarray data with an independent measurement of expression.

One interpretation of the summary in Table 4 is that the one study of pre-sepsis [12] found increased expression of pro-inflammatory genes and two of three studies of early sepsis ([7] and [13] but not [5]) found increased expression of pro-inflammatory genes. In contrast, in studies of late sepsis, three of six studies found increased expression of pro-inflammatory genes $[8,14,15]$ whereas three of six studies found decreased expression of proinflammatory genes $[9,14,16]$. Thus, there is very limited evidence that there is early pro-inflammatory gene expression and then later, balanced pro- and antiinflammatory gene expression.

The balance of pro- to anti-inflammatory gene expression is difficult to quantify. Do any studies attempt to quantitate a ratio of pro- to anti-inflammatory gene expression? Even such a simplistic approach ignores differing potency of different proteins. Is threefold expression of tumor necrosis factor-alpha really balanced biologically by threefold expression of interleukin-10?

Sample size is highly variable in the studies $(\mathrm{n}=12$ to 176) reviewed by Tang and colleagues [1]. Sample size is clearly important, especially in studies with many outcome variables (gene expression levels). We need to know how often power and sample size were calculated and how often statistical power was adequate with adjustments for multiple comparisons. This is important since the main story of Tang and colleagues [1] is negative: there is no evidence of a clear pro- and then anti-inflammatory pattern of gene expression. Yet this could be a false negative if the studies were underpowered for such a question.

I agree with Tang and colleagues [1] that the variability in the quality of statistical methods in studies of gene expression in human sepsis is very important and deserves more emphasis in the literature and in reviews such as that of Tang and colleagues. Most non-expert readers need a deeper explanation of the statistical methods that are desirable and how these vary across studies.

Interestingly, Tang and colleagues do not comment on how therapies alter gene expression in sepsis [17].

In my opinion, the above limitations of studies and the authors' summary of the literature require a leap of faith to suggest that the paradigm of sepsis as a proinflammatory phenotype that shifts to an anti-inflammatory phenotype is fundamentally flawed. In other words, the absence of evidence in these expression studies is not the same as having well-conducted studies with clear negative evidence. While Tang and colleagues may be on the right route, they have not reached the summit. There are tough and perhaps impassable cruxes ahead.

\section{Competing interests}

JAR holds stock in Sirius Genomics Inc. (Vancouver, BC, Canada), which has submitted patents that are owned by the University of British Columbia and licensed to Sirius Genomics Inc. and that are related to the genetics of sepsis and its treatment. The University of British Columbia has also submitted a patent related to the use of vasopressin in septic shock. JAR is an inventor on these patents. He has received consulting fees from Ferring Pharmaceuticals (Saint-Prex, Switzerland) (which manufactures vasopressin and is developing a selective V1a agonist), from AstraZeneca (London, UK) (which is developing an anti-tumor necrosis factor-alpha), and from Sirius Genomics Inc. He has received grant support from Sirius Genomics Inc., Ferring Pharmaceuticals, AstraZeneca, and Eli Lilly and Company (Indianapolis, IN, USA). He has received speaking honoraria from Pfizer Inc (New York, NY, USA) and Eli Lilly and Company.

Published: 11 February 2011

\section{References}

1. Tang BM, Huang SJ, McLean AS: Genome-wide transcription profiling of human sepsis: a systematic review. Crit Care 2010, 14:R237.

2. Modlin RL, Brightbill HD, Godowski PJ: The toll of innate immunity on microbial pathogens. N Engl J Med 1999, 340:1834-1835.

3. Tang BM, McLean AS, Huang SJ, Dawes IW, Ruby CY: Gene-expression profiling of peripheral blood mononuclear cells in sepsis. Crit Care Med 2009, 37:2324.

4. Payen D, Lukaszewicz AC, Belikova I, Faivre V, Gelin C, Russwurm S, Launay JM, Sevenet N: Gene profiling in human blood leucocytes during recovery from septic shock. Intensive Care Med 2008, 34:1371-1376.

5. Talwar S, Munson PJ, Barb J, Fiuza C, Cintron AP, Logun C, Tropea M, Khan S, Reda D, Shelhamer JH, Danner RL, Suffredini AF: Gene expression profiles of peripheral blood leukocytes after endotoxin challenge in humans. Physiol Genomics 2006, 25:203-215.

6. Ramilo O, Allman W, Chung W, Mejias A, Ardura M, Glaser C, Wittkowski KM, Piqueras B, Banchereau J, Palucka AK, Chaussabel D: Gene expression patterns in blood leukocytes discriminate patients with acute infections. Blood 2007, 109:2066-2077.

7. Prabhakar U, Conway TM, Murdock P, Mooney JL, Clark S, Hedge P, Bond BC, Jazwinska EC, Barnes MR, Tobin F, Damian-lordachi V, Greller L, Hurle M, 
Stubbs AP, Li Z, Valoret El, Erickson-Miller C, Cass L, Levitt B, Davis HM, Jorkasky DK, Williams WV: Correlation of protein and gene expression profiles of inflammatory proteins after endotoxin challenge in human subjects. DNA Cell Biol 2005, 24:410-431.

8. Cobb JP, Moore EE, Hayden DL, Minei JP, Cuschieri J, Yang J, Li Q, Lin N, Brownstein BH, Hennessy L, Mason PH, Schierding WS, Dixon DJ, Tompkins RG, Warren HS, Schoenfeld DA, Maier RV: Validation of the Riboleukogram to Detect Ventilator-Associated Pneumonia After Severe Injury. Ann Surg 2009 Aug 27. [Epub ahead of print].

9. Tang BM, MCLean AS, Dawes IW, Huang SJ, Cowley MJ, Lin RC: Geneexpression profiling of gram-positive and gram-negative sepsis in critically ill patients. Crit Care Med 2008, 36:1125-1128.

10. Brazma A, Hingamp P, Quackenbush J, Sherlock G, Spellman P, Stoeckert C, Aach J, Ansorge W, Ball CA, Causton HC, Gaasterland T, Glenisson P, Holstege FC, Kim IF, Markowitz V, Matese JC, Parkinson H, Robinson A, Sarkans U, Schulze-Kremer S, Stewart J, Taylor R, Vilo J, Vingron M: Minimum information about a microarray experiment (MIAME)-toward standards for microarray data. Nat Genet 2001, 29:365-371.

11. Dupuy A, Simon RM: Critical review of published microarray studies for cancer outcome and guidelines on statistical analysis and reporting. J Natl Cancer Inst 2007, 99:147-157.

12. Johnson SB, Lissauer M, Bochicchio GV, Moore R, Cross AS, Scalea TM: Gene expression profiles differentiate between sterile SIRS and early sepsis. Ann surg 2007, 245:611-621.

13. Calvano SE, Xiao W, Richards DR, Felciano RM, Baker HV, Cho RJ, Chen RO,
Brownstein BH, Cobb JP, Tschoeke SK, Miller-Graziano C, Moldawer LL, Mindrinos MN, Davis RW, Tompkins RG, Lowry SF; Inflamm and Host Response to Injury Large Scale Collab. Res. Program: A network-based analysis of systemic inflammation in humans. Nature 2005, 437:1032-1037.

14. Prucha M, Ruryk A, Boriss H, Möller E, Zazula R, Herold I, Claus RA, Reinhart KA, Deigner $P$, Russwurm S: Expression profiling: toward an application in sepsis diagnostics. Shock 2004, 22:29-33.

15. Wong HR, Shanley TP, Sakthivel B, Cvijanovich N, Lin R, Allen GL, Thomas NJ, Doctor A, Kalyanaraman M, Tofil NM, Penfil S, Monaco M, Tagavilla MA, Odoms K, Dunsmore K, Barnes M, Aronow BJ; Genomics of Pediatric SIRS/ Septic Shock Investigators: Genome-level expression profiles in pediatric septic shock indicate a role for altered zinc homeostasis in poor outcome. Physiol Genomics 2007, 30:146-155.

16. Tang BM, McLean AS, Dawes IW, Huang SJ, Lin RC: The use of geneexpression profiling to identify candidate genes in human sepsis. Am J Respir Crit Care Med 2007, 176:676-684.

17. Joyce DE, Gelbert L, Ciaccia A, DeHoff B, Grinnell BW: Gene expression profile of antithrombotic protein c defines new mechanisms modulating inflammation and apoptosis. J Biol Chem 2001, 276:11199-11203.

doi:10.1186/cc9384

Cite this article as: Russell JA: Gene expression in human sepsis: what have we learned? Critical Care 2011, 15:121. 